\title{
A systematic review of the role of non-magnified endoscopy for the assessment of $H$. pylori infection
}

\section{다)(요 $\odot$}

\author{
Authors \\ Ben Glover ${ }^{1}$, Julian Teare ${ }^{1}$, Nisha Patel $^{2}$ \\ Institutions \\ 1 Imperial College London Department of Surgery and \\ Cancer - Surgery and Cancer, London, England, UK \\ 2 Imperial College London Department of Surgery and \\ Cancer - Gastroenterology, London, England, UK
}

submitted 14.3.2019

accepted after revision 11.6.2019

Bibliography

DOI https://doi.org/10.1055/a-0999-5252 |

Endoscopy International Open 2020; 08: E105-E114

(c) Georg Thieme Verlag KG Stuttgart · New York elSSN 2196-9736

Corresponding author

Dr. Nisha Patel, MBBS, BSc, PhD, Imperial College

Healthcare NHS Trust, Department of Gastroenterology, Charing Cross Hospital, Fulham Palace Rd, Hammersmith W6 8RF, United Kingdom of Great Britain and Northern Ireland

nisha.patel8@nhs.net

\section{ABSTRACT}

Background and study aims There is growing interest in the endoscopic recognition of Helicobacter pylori infection, and application to routine practice. We present a systematic review of the current literature regarding diagnosis of
H. pylori during standard (non-magnified) endoscopy, including adjuncts such as image enhancement and computer-aided diagnosis.

Method The Medline and Cochrane databases were searched for studies investigating performance of non-magnified optical diagnosis for $H$. pylori, or those which characterized mucosal features associated with $H$. pylori infection. Studies were preferred with a validated reference test as the comparator, although they were included if at least one validated reference test was used.

Results Twenty suitable studies were identified and included for analysis. In total, 4,703 patients underwent investigation including white light endoscopy, narrow band imaging, i-scan, blue-laser imaging, and computer-aided diagnostic techniques. The endoscopic features of $H$. pylori infection observed using each modality are discussed and diagnostic accuracies reported. The regular arrangement of collecting venules (RAC) is an important predictor of the H. pylori-naïve stomach. "Mosaic" and "mottled" patterns have a positive association with $H$. pylori infection. The "cracked" pattern may be a predictor of an $\mathrm{H}$. pylori-negative stomach following eradication.

Conclusions This review summarizes current progress made in endoscopic diagnosis of $H$. pylori infection. At present there is no single diagnostic approach that provides validated diagnostic accuracy. Further prospective studies are required, as is development of a validated classification system. Early studies in computer-aided diagnosis suggest potential for a high level of accuracy but real-time results are awaited.

\section{Introduction}

H. pylori is a common global pathogen, and infection is a known risk factor for gastric disorders including gastritis, peptic ulcer, and adenocarcinoma [1]. Diagnosis of $H$. pylori infection identifies patients at higher risk of these conditions and allows eradication therapy to be initiated, with resultant reduction of morbidity, including development of gastric cancer [2]. Conventional diagnostic tests for $H$. pylori include noninvasive methods such as stool antigen testing, serology,+or the urea breath test. These deliver a high level of accuracy regarding $H$. pylori status, but do not provide endoscopic information regarding the gastric mucosa and any abnormality. Invasive investigations for $H$. pylori include the rapid urease test, tissue microscopy, and tissue culture. Due to the focal or patchy nature of $H$. pylori infection, there is potential for sampling error and diagnostic inaccuracy [3].

There is potential benefit, therefore, from being able to endoscopically predict presence or absence of $H$. pylori within an area of gastric mucosa. An approach with sufficient diagnostic accuracy could distinguish areas of infected mucosa and allow targeted biopsy, with greater diagnostic yield from the invasive tests for $\mathrm{H}$. pylori. It could even be possible to avoid the need for biopsy if infection could be reliably predicted. Further- 
more, endoscopic appearance of the stomach may be altered following eradiation of $\mathrm{H}$. pylori and it is therefore important to be able to distinguish these changes from infected or $\mathrm{H}$. pylorinaïve mucosa. Modern endoscopic platforms offer high-resolution images and the benefit of image-enhanced endoscopy (IEE) techniques, to allow inspection of the gastric mucosa at a level of detail not previously possible [4].

$A$ recent Chinese meta-analysis investigated the diagnostic accuracy of magnifying endoscopy for $H$. pylori infection, both with and without IEE or chromoendoscopy [5]. The results suggest that the optimum method of diagnosis includes assessment of pit and vascular patterns, and that this approach is most accurate in the gastric body, compared to the antrum. However, magnifying endoscopy is less commonly used by western endoscopists, and is typically employed in specialist centers by expert operators. Diagnosis of $H$. pylori by non-magnifying endoscopy would therefore be of great interest to the general endoscopist, should it be found to be accurate and reproducible. Initial studies in non-magnifying endoscopy found disappointing results, with low sensitivity $(18 \%-75 \%)$ and poor inter-operator agreement [6-8]. These studies were performed using endoscopic equipment with lower resolution than is currently in general use, and were unable to assess fine vascular patterns; gross morphology of the gastric mucosa was examined instead. With the advent of high-resolution endoscopic platforms from the major manufacturers, more recent studies have attempted to further investigate the diagnostic performance of high-resolution, non-magnified endoscopic examination for presence of $H$. pylori infection. We will discuss the current literature and relevant studies, including the impact of IEE and future developments, which include second-generation IEE systems such as blue laser imaging (BLI) and linked Color imaging ( $\mathrm{LCl}$ ). In addition to this, we discuss the exciting advances in computer-aided diagnosis (CAD), made possible by modern high-quality endoscopic images, combined with machinelearning processes.

\section{Method}

\section{Search strategy}

This review was registered with the PROSPERO register of systematic reviews (No.CRD42019123413). We systematically searched the databases of Medline and the Cochrane Library to identify relevant articles. The search terms "Helicobacter pylori," "H. pylori," "HP," and "gastritis" were combined with the search terms "narrow band," "i-scan," "iscan," "narrowband," "optical biopsy," “image enhanc*," "IEE," and "chromoendoscopy." After scanning the titles and abstracts, articles were excluded if they did not meet the inclusion criteria. The abstracts and full text of the remaining articles were read, and a secondary search of the references was performed for any eligible studies that had been missed by the original search. A summary of the included studies is shown in $>$ Table 1 . On review of the included studies, there was a high degree of heterogeneity, and many of the studies were descriptive rather than diagnostic. It was therefore decided that statistical analysis of diagnostic accuracy would not be possible, and results would not be illuminating.
Selection of studies for review:

The inclusion criteria were as follows:

- Endoscopy was used for visual diagnosis of $H$. pylori infection, or description of endoscopic features that could predict infection.

- The following reference standards were applied: Histological examination, serology, stool antigen testing, rapid urease test (RUT), or urea breath test (UBT). Studies with two or more of these methods used for diagnosis were preferred, but all studies using these reference standards were considered.

- The study was available in English.

The exclusion criteria were as follows:

- Magnified endoscopy alone was studied.

- Studies that overlapped the data already included, without adding new analysis.

- Studies without original research (review articles, opinion letters, comments)

\section{Results}

Study characteristics and summary of results for the studies are presented in $>$ Table 1. White-light endoscopy (WLE) has demonstrated the RAC, and suggested it confers a negative predictive value (NPV) of $>90 \%$ for $\mathrm{H}$. pylori infection. Abnormal patterns including antral nodularity and mosaic patterns are also visible using WLE, although diagnostic predictive power of these patterns is poor for predicting $H$. pylori positive status. Abnormal mucosal patterns predictive of current $H$. pylori infection include mosaic, mottled or spotty appearances.

Narrow-band imaging (NBI) has further characterized the mucosal features including rod-and cone-shaped gastric pits, prominent gastric sulci, ground glass appearance, dark brown patches with a blueish margin, and yellowish-white nodules (identified as lymphoid follicles). Again, these have shown good sensitivity and specificity for $H$. pylori infection but have not yet been validated in a prospective patient series.

A pilot study of i-scan has suggested that it is superior for identifying features of $H$. pylori infection vs white light alone.

A "cracked" mucosal appearance has been identified using modern high-resolution BLI equipment, and may represent the appearance of the mucosa after eradication of $H$. pylori infection.

CAD techniques have shown high levels of diagnostic accuracy for distinguishing between images of $H$. pylori infected mucosa, and $H$. pylori negative mucosa.

\section{White-light endoscopy}

Endoscopic examination under white light is the basic diagnostic modality during a routine upper Gl endoscopy. It would therefore be desirable to be able to identify characteristics of both $H$. pylori infection, and of the $H$. pylori negative stomach under white light endoscopy (WLE).

Early studies in endoscopic diagnosis of $H$. pylori were performed with standard-definition endoscopic equipment; in 2003 Redéen et al. identified several potential endoscopic fea- 
- Table 1 Summary of study characteristics. Ordered by primary imaging modality, and date of publication.

\begin{tabular}{|c|c|c|c|c|c|c|c|}
\hline Author & Year & Country & $\begin{array}{l}\text { Imaging } \\
\text { modality }\end{array}$ & $\begin{array}{l}\text { Reference } \\
\text { standard }\end{array}$ & $\begin{array}{l}\text { Number } \\
\text { of pa- } \\
\text { tients }\end{array}$ & $\begin{array}{l}\text { Mucosal criteria } \\
\text { investigated }\end{array}$ & Diagnostic accuracy \\
\hline $\begin{array}{l}\text { Redeen } \\
\text { et al. }\end{array}$ & 2003 & Sweden & WLE & $\begin{array}{l}\text { Histology, } \\
\text { rapid ur- } \\
\text { ease test }\end{array}$ & 488 & $\begin{array}{l}\text { Identified features including } \\
\text { the absence of corpal rugae, } \\
\text { erythema (diffuse, spotty, lin- } \\
\text { ear), gastric erosions and pres- } \\
\text { ence of visible vessels. }\end{array}$ & $\begin{array}{l}\text { Showed sensitivity } 75 \% \text { and } \\
\text { specificity } 63 \% \text { for diagnosis of } \\
\text { current } H \text {. pylori infection. Im- } \\
\text { age assessment was conduct- } \\
\text { ed retrospectively. }\end{array}$ \\
\hline Yan et al. & 2010 & China & WLE & $\begin{array}{l}\text { Histology, } \\
\text { rapid ur- } \\
\text { ease test }\end{array}$ & 112 & $\begin{array}{l}\text { Categorised four gastric mu- } \\
\text { cosal patterns, including the } \\
\text { RAC, cleft-like mucosa, mosa- } \\
\text { ic, and mosaic with focal hy- } \\
\text { peraemia. }\end{array}$ & $\begin{array}{l}\text { The presence of either of the } \\
\text { two "mosaic" patterns were } \\
\text { reported as having sensitivity } \\
\text { and specificity of } 100 \% \text { and } \\
86 \% \text { for the presence of } \mathrm{H} \text {. py- } \\
\text { lori-positive status. } \\
\text { The RAC was reported as } \\
\text { showing sensitivity of } 20 \% \text { and } \\
\text { specificity of } 100 \% \text { for predic- } \\
\text { tion of } \mathrm{H} \text {. pylori negative status. } \\
\text { Patient recruitment was pro- } \\
\text { spective, but image analysis } \\
\text { was retrospective. }\end{array}$ \\
\hline $\begin{array}{l}\text { Alaboudy } \\
\text { et al. }\end{array}$ & 2011 & Japan & WLE & $\begin{array}{l}\text { Histology, } \\
\text { urea } \\
\text { breath test }\end{array}$ & 402 & $\begin{array}{l}\text { Investigated the RAC, sug- } \\
\text { gested that presence of RAC is } \\
\text { likely to exclude } H \text {. pylori infec- } \\
\text { tion. }\end{array}$ & $\begin{array}{l}\text { RAC shows sensitivity and } \\
\text { negative predictive value of } \\
94.7 \% \text { and } 98,1 \% \text { in patients } \\
\text { under the age of } 60 \text {. In patients } \\
\text { over the age of } 60 \text {, these fall to } \\
80 \% \text { and } 93 \% \text {. }\end{array}$ \\
\hline Cho et al. & 2013 & Korea & WLE & $\begin{array}{l}\text { Histology, } \\
\text { rapid ur- } \\
\text { ease test }\end{array}$ & 621 & $\begin{array}{l}\text { Categorised four distinct mu- } \\
\text { cosal appearances including } \\
\text { the RAC, mosaic pattern, dif- } \\
\text { fuse homogeneous redness } \\
\text { and 'atypical'. }\end{array}$ & $\begin{array}{l}\text { The presence of any of the } \\
\text { "abnormal" mucosal patterns } \\
\text { predicted } H \text {. pylori infection } \\
\text { with sensitivity } 93.3 \% \text {, specifi- } \\
\text { city } 89.1 \% \text {. Patient recruit- } \\
\text { ment was prospective, and im- } \\
\text { age analysis was retrospective. }\end{array}$ \\
\hline $\begin{array}{l}\text { Wata- } \\
\text { nabe } \\
\text { et al. }\end{array}$ & 2013 & Japan & WLE & $\begin{array}{l}\text { Histology, } \\
\text { serology, } \\
\text { rapid ur- } \\
\text { ease test }\end{array}$ & 77 & $\begin{array}{l}\text { Identified that the diagnostic } \\
\text { accuracy is greatest in } \mathrm{H} \text {. pylori } \\
\text { naïve patients, and declines in } \\
\text { patients with previous } \mathrm{H} \text {. pylori } \\
\text { eradication. Also demonstrat- } \\
\text { ed good inter-operator agree- } \\
\text { ment for features of } \mathrm{H} \text {. pylori } \\
\text { infection and a fast learning } \\
\text { curve. }\end{array}$ & $\begin{array}{l}\text { In the } H \text {. pylori negative stom- } \\
\text { ach, the diagnostic accuracy } \\
\text { was } 88.9 \% \text {, although this fell to } \\
62.1 \% \text { for patients with current } \\
\text { H. pylori infection, and to } \\
55.8 \% \text { for patients with eradi- } \\
\text { cated } H \text {. pylori. }\end{array}$ \\
\hline $\begin{array}{l}\text { Gomes } \\
\text { et al. }\end{array}$ & 2016 & Brazil & WLE & $\begin{array}{l}\text { Histology, } \\
\text { rapid ur- } \\
\text { ease test }\end{array}$ & 339 & $\begin{array}{l}\text { Identified RAC, streaky ery- } \\
\text { thema, fundic gland polyps } \\
\text { and mucosal atrophy as nega- } \\
\text { tive predictors for H. pylori in- } \\
\text { fection. }\end{array}$ & $\begin{array}{l}\text { The factors found to be most } \\
\text { strongly associated with infec- } \\
\text { tion were antral nodularity } \\
\text { ( } 26.9 \%) \text {, raised erosion } \\
\text { ( } 15.38 \%) \text {, and a mosaic pat- } \\
\text { tern in the body ( } 21.2 \%) \text {. } \\
\text { Patients were recruited pro- } \\
\text { spectively, images were ana- } \\
\text { lysed retrospectively. }\end{array}$ \\
\hline $\begin{array}{l}\text { Matra- } \\
\text { kool et al. }\end{array}$ & 2016 & Thailand & WLE & $\begin{array}{l}\text { Histology, } \\
\text { rapid ur- } \\
\text { ease test }\end{array}$ & 200 & $\begin{array}{l}\text { Classified mucosal morpholo- } \\
\text { gy into four subtypes including } \\
\text { RAC, clefts, mosaic, and mo- } \\
\text { saic with focal hyperaemia. }\end{array}$ & $\begin{array}{l}\text { Assessed using a similar classi- } \\
\text { fication as Yan et al. Presence } \\
\text { of RAC or clefts (Type I or II) } \\
\text { predicted } H \text {. pylori negative } \\
\text { status with } 85 \% \text { accuracy. } \\
\text { Presence of either mosaic pat- } \\
\text { tern predicted } H \text {. pylori positive } \\
\text { status with } 92 \% \text { accuracy. }\end{array}$ \\
\hline
\end{tabular}


- Table 1 (Continuation)

\begin{tabular}{|c|c|c|c|c|c|c|c|}
\hline Author & Year & Country & $\begin{array}{l}\text { Imaging } \\
\text { modality }\end{array}$ & $\begin{array}{l}\text { Reference } \\
\text { standard }\end{array}$ & $\begin{array}{l}\text { Number } \\
\text { of pa- } \\
\text { tients }\end{array}$ & $\begin{array}{l}\text { Mucosal criteria } \\
\text { investigated }\end{array}$ & Diagnostic accuracy \\
\hline $\begin{array}{l}\text { Alaboudy } \\
\text { et al. }\end{array}$ & 2011 & Japan & NBI & Histology & 20 & $\begin{array}{l}\text { Defined five distinct mucosal } \\
\text { patterns under NBI including } \\
\text { RAC. Abnormal mucosa pre- } \\
\text { dicted H. pylori positive, and } \\
\text { RAC predicted H. pylori nega- } \\
\text { tive. }\end{array}$ & $\begin{array}{l}\text { Patients were selected for } \\
\text { biopsy based on mucosal ap- } \\
\text { pearances. The RAC was asso- } \\
\text { ciated with histologically nor- } \\
\text { mal mucosa. The cone-shaped, } \\
\text { rod-shaped, ground-glass and } \\
\text { dark brown patches mucosal } \\
\text { patterns were associated with } \\
\text { histological evidence of } H \text {. py- } \\
\text { lori infection and a degree of } \\
\text { neutrophil or lymphocyte infil- } \\
\text { tration. }\end{array}$ \\
\hline $\begin{array}{l}\text { Özgür } \\
\text { et al. }\end{array}$ & 2015 & Turkey & NBI & $\begin{array}{l}\text { Urea } \\
\text { breath } \\
\text { test, rapid } \\
\text { urease } \\
\text { test, tissue } \\
\text { culture }\end{array}$ & 165 & $\begin{array}{l}\text { Study in paediatric population. } \\
\text { Mucosal appearances classi- } \\
\text { fied according to Alaboudy et } \\
\text { al. }\end{array}$ & $\begin{array}{l}\text { Patients were recruited pro- } \\
\text { spectively. The mucosal } \\
\text { changes described by Alabou- } \\
\text { dy were further visualised un- } \\
\text { der NBI. Sensitivity of } 92.9 \% \\
\text { was found for } H \text {. pylori infec- } \\
\text { tion, in patients with abnormal } \\
\text { gastric mucosa. Specificity was } \\
62.4 \% \text {. }\end{array}$ \\
\hline $\begin{array}{l}\text { Tongta- } \\
\text { wee } \\
\text { et al. (1) }\end{array}$ & 2015 & Thailand & NBI & $\begin{array}{l}\text { Histology, } \\
\text { rapid ur- } \\
\text { ease test }\end{array}$ & 200 & $\begin{array}{l}\text { Proposed five mucosal pat- } \\
\text { terns including RAC, cone- } \\
\text { shaped gastric pits, rod- } \\
\text { shaped pits with sulci, ground- } \\
\text { glass morphology, dark brown } \\
\text { patches with blueish margin } \\
\text { and irregular border. }\end{array}$ & $\begin{array}{l}\text { The mucosal patterns de- } \\
\text { scribed by Alaboudy were as- } \\
\text { sessed retrospectively follow- } \\
\text { ing endoscopy. Type } 3,4,5 \text { mu- } \\
\text { cosal pattern showed sensitiv- } \\
\text { ity } 94.3 \% \text { and specificity } 96.7 \% \\
\text { for predicting H. pylori positiv- } \\
\text { ity. Presence of RAC predicted } \\
\text { H. pylori negative status in } \\
100 \% \text { of patients. }\end{array}$ \\
\hline $\begin{array}{l}\text { Tongta- } \\
\text { wee } \\
\text { et al. (2) }\end{array}$ & 2015 & Thailand & NBI & $\begin{array}{l}\text { Histology, } \\
\text { rapid ur- } \\
\text { ease test }\end{array}$ & 500 & $\begin{array}{l}\text { Demonstrated increased diag- } \\
\text { nostic yield when NBI was used } \\
\text { to select biopsy sites. }\end{array}$ & $\begin{array}{l}\text { In the patient group with gas- } \\
\text { tric biopsies targeted to areas } \\
\text { of abnormal mucosa, sensitiv- } \\
\text { ity of } 95.4 \% \text { and specificity } \\
97.3 \% \text { were achieved. The non- } \\
\text { targeted group were } 93.0 \% \\
\text { and } 88.6 \% \text { respectively. }\end{array}$ \\
\hline $\begin{array}{l}\text { Pimen- } \\
\text { tal- } \\
\text { Nunes } \\
\text { et al. }\end{array}$ & 2016 & $\begin{array}{l}\text { Portugal, } \\
\text { Italy, Ro- } \\
\text { mania, } \\
\text { USA, UK. }\end{array}$ & $\mathrm{NBI}$ & Histology & 238 & $\begin{array}{l}\text { The first clinical trial to pro- } \\
\text { spectively evaluate the ability } \\
\text { of NBI features to predict } \mathrm{H} \text {. } \\
\text { pylori status. Primarily eval- } \\
\text { uated other gastric premalig- } \\
\text { nant conditions. }\end{array}$ & $\begin{array}{l}\text { The accuracy of white-light vs } \\
\text { narrow-band imaging was not } \\
\text { found to be significantly dif- } \\
\text { ferent ( } 73 \% \text { and } 74 \% \text { respec- } \\
\text { tively). This is currently the } \\
\text { only study to predict the diag- } \\
\text { nosis prospectively. }\end{array}$ \\
\hline $\begin{array}{l}\text { Hayashi } \\
\text { et al. }\end{array}$ & 2018 & Japan & NBI & $\begin{array}{l}\text { Histology, } \\
\text { urea } \\
\text { breath test }\end{array}$ & 211 & $\begin{array}{l}\text { Characterised the features and } \\
\text { significance of "yellowish- } \\
\text { white nodules" (YWN) under } \\
\text { NBI. }\end{array}$ & $\begin{array}{l}\text { Defined that the YWN are likely } \\
\text { to represent lymphoid follicles } \\
\text { (96\%) agreement with histolo- } \\
\text { gy. Diagnostic predictions for } \\
\text { H. pylori status were not made } \\
\text { during this study. }\end{array}$ \\
\hline
\end{tabular}


Table 1 (Continuation)

\begin{tabular}{|c|c|c|c|c|c|c|c|}
\hline Author & Year & Country & $\begin{array}{l}\text { Imaging } \\
\text { modality }\end{array}$ & $\begin{array}{l}\text { Reference } \\
\text { standard }\end{array}$ & $\begin{array}{l}\text { Number } \\
\text { of pa- } \\
\text { tients }\end{array}$ & $\begin{array}{l}\text { Mucosal criteria } \\
\text { investigated }\end{array}$ & Diagnostic accuracy \\
\hline $\begin{array}{l}\text { Sharma } \\
\text { et al. }\end{array}$ & 2018 & India & I-scan & $\begin{array}{l}\text { Rapid ur- } \\
\text { ease test }\end{array}$ & 146 & $\begin{array}{l}\text { Assessed features including } \\
\text { abnormal vascularity, mosaic } \\
\text { pattern, pit pattern, spider } \\
\text { web pattern and abnormal } \\
\text { light reflex. }\end{array}$ & $\begin{array}{l}\text { Currently the only study inves- } \\
\text { tigating i-scan imaging. Diag- } \\
\text { nostic accuracy was reported } \\
\text { as greater than WLE, at } 97 \% \text { vs } \\
78 \% \text {. Rapid Urease Test was the } \\
\text { only reported diagnostic refer- } \\
\text { ence standard. }\end{array}$ \\
\hline $\begin{array}{l}\text { Dohi } \\
\text { et al. }\end{array}$ & 2016 & Japan & $\mathrm{LCl}$ & $\begin{array}{l}\text { Histology, } \\
\text { rapid ur- } \\
\text { ease test, } \\
\text { serology, } \\
\text { urea } \\
\text { breath test }\end{array}$ & 60 & $\begin{array}{l}\text { Retrospectively examined the } \\
\text { diagnostic potential of a dif- } \\
\text { fuse erythematous appear- } \\
\text { ance of the fundus, under } \mathrm{LCl} \text {. }\end{array}$ & $\begin{array}{l}\text { Overall diagnostic accuracy for } \\
\text { H. pylori positive or negative } \\
\text { status was reported as } 85.8 \% \\
\text { on this retrospective review of } \\
\text { endoscopic images. }\end{array}$ \\
\hline $\begin{array}{l}\text { Nishika- } \\
\text { wa et al. }\end{array}$ & 2017 & Japan & BLI & $\begin{array}{l}\text { Previous } \\
\text { H. Pylori- } \\
\text { positive }\end{array}$ & 441 & $\begin{array}{l}\text { Classified mucosa in patients } \\
\text { with atrophic gastritis into } \\
\text { "spotty," "cracked" or "mot- } \\
\text { tled' appearances under BLI. }\end{array}$ & $\begin{array}{l}\text { The "spotty" pattern correlat- } \\
\text { ed with } H \text {. pylori infection in } \\
86 \% \text { of patients with active in- } \\
\text { fection. Sensitivity and specifi- } \\
\text { city were } 95.3 \% \text { and } 86.5 \% \text {. } \\
\text { The 'cracked' pattern was ob- } \\
\text { served in patients with pre- } \\
\text { vious } H \text {. pylori infection, during } \\
\text { inspection at post-eradication } \\
\text { endoscopy. }\end{array}$ \\
\hline $\begin{array}{l}\text { Chen } \\
\text { et al. }\end{array}$ & 2018 & Taiwan & $\mathrm{LCl}$ & $\begin{array}{l}\text { Histology, } \\
\text { urea } \\
\text { breath test }\end{array}$ & 122 & $\begin{array}{l}\text { Applied the classification of } \\
\text { Dohi et al. prospectively, with } \\
\text { both } \mathrm{LCl} \text { and magnified LCI. }\end{array}$ & $\begin{array}{l}\text { Diagnostic accuracy of non- } \\
\text { magnified } \mathrm{LCl} \text { was } 78.4 \% \text {, with } \\
\text { sensitivity and specificity of } \\
70.8 \% \text { and } 91.3 \% \text { respectively. } \\
\text { Diagnostic accuracy was not } \\
\text { significantly different from } \\
\text { magnified-LCI. }\end{array}$ \\
\hline Itoh et al. & 2017 & Japan & $\begin{array}{l}\text { CAD } \\
(W L E)\end{array}$ & Serology & 139 & $\begin{array}{l}149 \text { images of mucosal pat- } \\
\text { terns from } 139 \text { patients were } \\
\text { used to train a convolutional } \\
\text { neural network to identify } \mathrm{H} \text {. } \\
\text { pylori status. }\end{array}$ & $\begin{array}{l}\text { Presence of } H \text {. pylori positivity } \\
\text { was detected by the CNN with } \\
\text { sensitivity of } 86.7 \% \text { and speci- } \\
\text { ficity of } 86.7 \% \text {. The AUC was } \\
0.956 \text {. }\end{array}$ \\
\hline $\begin{array}{l}\text { Shichijo } \\
\text { et al. }\end{array}$ & 2017 & Japan & $\begin{array}{l}\text { CAD } \\
\text { (WLE) }\end{array}$ & $\begin{array}{l}\text { Serology, } \\
\text { stool anti- } \\
\text { gen, urea } \\
\text { breath test }\end{array}$ & $\mathrm{N} / \mathrm{K}$ & $\begin{array}{l}32,208 \text { images of mucosal } \\
\text { patterns were used for training } \\
\text { of a convolutional neural net- } \\
\text { work (CNN) to identify H. pylori } \\
\text { status. }\end{array}$ & $\begin{array}{l}\text { Retrospective analysis of } \\
\text { endoscopic images was per- } \\
\text { formed. Diagnostic accuracy of } \\
87.7 \% \text { was achieved by the } \\
\text { CNN, compared with } 82.4 \% \text { for } \\
\text { human endoscopists. }\end{array}$ \\
\hline $\begin{array}{l}\text { Nakashi- } \\
\text { ma et al. }\end{array}$ & 2018 & Japan & $\begin{array}{l}\text { CAD (BLI, } \\
L C I)\end{array}$ & Serology & 222 & $\begin{array}{l}\text { Approximately } 2,000 \text { images } \\
\text { were used to train a CNN to } \\
\text { identify } \mathrm{H} \text {. pylori status. The } \\
\text { artificial intelligence could also } \\
\text { produce 'heat maps to show } \\
\text { the region of interest. }\end{array}$ & $\begin{array}{l}\text { Automated analysis was un- } \\
\text { dertaken of images obtained } \\
\text { under WLE, with sensitivity and } \\
\text { specificity of } 66.7 \% \text { and } 60.0 \% \text {. } \\
\text { Under BLI-bright and LCI } \\
\text { modes, sensitivity increased to } \\
96.7 \% \text {, and specificity in- } \\
\text { creased to } 86.7 \% \text { for BLI-bright } \\
\text { and } 83.3 \% \text { for LCI. }\end{array}$ \\
\hline
\end{tabular}

WLE, white light endoscopy; RAC, regular arrangement of collecting vessels; NBI, narrow-band imaging; YWN, yellowish-white nodules; LCI, linked color imaging; CAD, computer-aided diagnosis; BLI, blue laser imaging; CNN, convolutional neural network. 


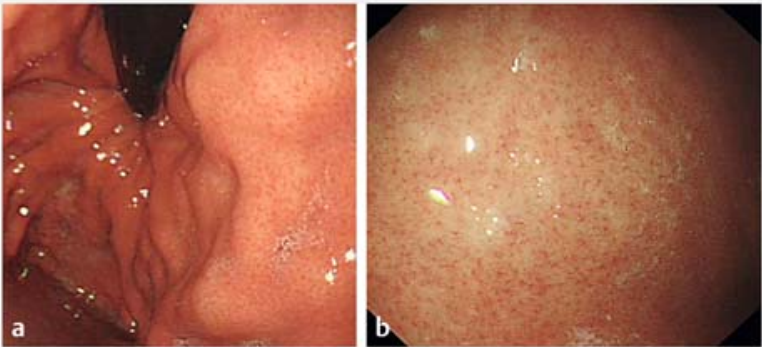

- Fig. 1 Regular arrangement of collecting venules. a RAC present in the upper gastric body. $\mathbf{b}$ RAC present in the lower gastric body.

tures of $H$. pylori by logistic regression analysis, including an abnormal antral texture, a mammillated corpus surface, and antral erosions as likely predictive factors for presence of $H$. pylori. When applied prospectively, however, the sensitivity and specificity of these features was found to be only $75 \%$ and $63 \%$ [6]. Another study by Laine et al. identified antral nodularity as a strongly predictive factor for $\mathrm{H}$. pylori infection (PPV $90 \%$ ) and found good inter-operator agreement [7]. Importantly, in 2002 Yagi et al. described "minute points seen at regular intervals" in the stomach of $\mathrm{H}$. pylori-negative patients. This has been characterized as the "regular arrangement of collecting venules" (RAC), presence of which was reported as showing $93.8 \%$ sensitivity for diagnosing and $\mathrm{H}$. pylori-negative status [9]. Further studies in children and adolescents by Machado et al. in 2008 agreed that the positive finding of RAC is strongly predictive of $\mathrm{H}$. pylori-negative status, particularly in the absence of antral nodularity [10]. Further analysis of endoscopic images by Alaboudy et al. has supported the hypothesis that presence of RAC suggests absence of $H$. pylori infection, but also notes that the RAC may become less visible with increasing age, requiring caution in its interpretation for older patients [11]. - Fig. 1 shows the RAC present within a normal stomach, at the upper and lower gastric body.

In 2010, Yan et al. performed a study using high-resolution WLE in 112 patients experiencing dyspepsia to establish a classification of the mucosal patterns in the gastric corpus associated with $H$. pylori infection. This reported a "cleft-like" pattern, a "regular arrangement of red dots," a "mosaic appearance" and a "mosaic appearance with hyperaemia." The combined sensitivity, specificity, and NPV for H. pylori infection of the two "mosaic" patterns was reported as $100 \%, 86 \%$, and $100 \%$, respectively [12]. Although patient recruitment was prospective, analysis of the images and categorization was performed retrospectively, after the time of endoscopy. A similar classification was developed by Matrakool et al., who also demonstrated good correlation between the different endoscopic appearances and histological grade of inflammation [13].

Further characterization of the gastric mucosa in $\mathrm{H}$. pylori was studied by Cho et al. in 2013, using prospective recruitment of 617 patients and close examination of the gastric corpus. Four distinct mucosal patterns were again identified; the "regular arrangement of collecting vessels" (RAC) which was re-

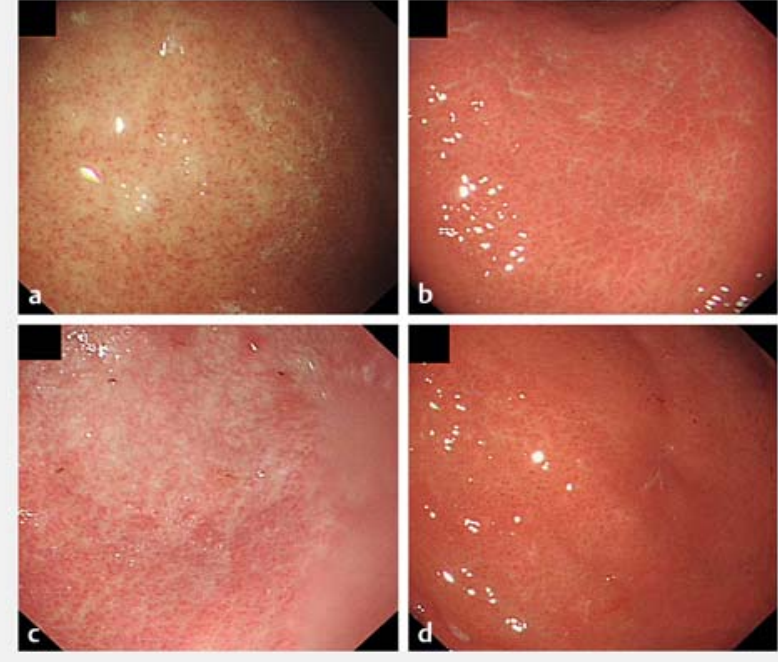

- Fig. 2 Mucosal patterns observed in the gastric corpus. a Normal, regular arrangement of collecting venules (RAC) pattern seen as numerous minute red dots. b Mosaic-like appearance characterized by prominent, swollen areae gastricae with deeper furrows or snake skin appearance. c Diffuse homogenous redness. d Atypical pattern of irregular redness with groove.

garded as normal, a "mosaic-like" appearance, "diffuse homogeneous redness" and "irregular redness with groove," which were regarded as abnormal. Presence of $H$. pylori infection could be predicted with a sensitivity of $93.3 \%$, specificity of $89.1 \%$, and overall accuracy of $91.6 \%$ in a patient with any of the "abnormal" patterns [14]. The mucosal appearances are shown in > Fig. 2.

Further characteristics of the $\mathrm{H}$. pylori-positive stomach were explored by Gomes et al. in 2016, who agreed that H. pylori infection is associated with antral nodularity and mosaic pattern in the corpus [15].

Another important consideration in assessment of $H$. pylori status is distinguishing between patients without previous H. pylori infection and those with eradicated infection. A study of endoscopic images from 77 patients with dyspepsia was performed in 2013 by Watanabe at al and grouped patients as $H$. pylori-naïve, $H$. pylori-infected, and $H$. pylori-eradicated. Diagnostic accuracy for $H$. pylori-naïve patients was $89 \%$, falling to $62.1 \%$ for infected patients and $55.8 \%$ for $\mathrm{H}$. pylori-eradicated patients [16]. The role of mucosal pattern recognition in diagnosis of $H$. pylori is still developing, and although the potential for high diagnostic accuracy has been demonstrated in studies of endoscopic images, more robust prospective trials are required to validate the accuracy of diagnostic predictions. An important area for development would be introduction of a unified classification system for prediction of $H$. pylori positivity and negativity, and improved understanding of the features of the stomach after $H$. pylori eradication. The RAC has been identified as an important predictor of the H. pylori-naïve stomach, and is clearly visible under WLE, without additional magnification. 


\section{Narrow-band Imaging}

The current generation of endoscopes from Olympus (Tokyo, Japan) incorporate optical filters, which can be activated during endoscopy to produce an altered-color image. There is interest in using this technique for NBI to further interrogate the mucosa for additional diagnostic information, not apparent using WLE.

NBI assessment of $H$. pylori was investigated in 2011 by Alaboudy et al., who retrospectively assessed endoscopic images of 300 patients with known $\mathrm{H}$. pylori, and devised a classification including five distinct mucosal appearances (Type 1: RAC present, Type 2: Cone-shaped gastric pits, Type 3: Rod-shaped gastric pits, prominent sulci, Type 4: Ground-glass appearance, Type 5: Dark brown patches, blueish margin, irregular border) [17]. Subsequently, 20 volunteers underwent endoscopy with biopsy, showing the RAC was also identifiable under NBI, and predicted $H$. pylori-negative status.

Further predictors of $H$. pylori status were investigated by Hayashi et al. In 2013, with a retrospective study of 211 patients with confirmed $H$. pylori, to investigate the significance of the "yellowish-white nodules" (YWN) which had been noted to appear frequently in the $H$. pylori-positive stomach and were postulated to correspond with lymphoid follicles [18]. These were examined under white light and NBI (also under magnified $\mathrm{NBI}$ ) and seen to be about 0.5 to $1 \mathrm{~mm}$ in diameter. Presence of YWN had a high specificity (96\%) for the histological finding of lymphoid follicles and may therefore act as a surrogate marker for the histological finding of nodular gastritis, associated with H. pylori infection.

Also in 2013, a prospective study in pediatric patients was performed by Özgür et al. to further investigate NBI findings associated with $H$. pylori infection [19]. Patients with dyspepsia or abdominal pain whose $H$. pylori status was unknown were enrolled and underwent endoscopic examination with white light and NBI. Endoscopic features of interest included findings of gastritis, nodular gastritis, or ulceration. This study found a greater proportion of mucosal changes in patients with $\mathrm{H}$. pylori infection, and furthermore discovered that these changes were more readily identifiable under NBI than WLE. A sensitivity of 92.9\% was achieved for $\mathrm{NBI}$ examination, with specificity $62.4 \%$.

Attempts were made to define diagnostic accuracy of the observable features in an $\mathrm{H}$. pylori-infected stomach by Tongtawee et al. in 2014 [20]. Two hundred patients with dyspepsia were examined endoscopically with white light and NBI, and the observed mucosal patterns were characterized according to the classification developed by Alaboudy et al. Presence of Type 3, 4 or 5 mucosal patterns was found to have a sensitivity of $94.3 \%$, with specificity of $96.7 \%$, for predicting $H$. pylori positivity. It should be further noted that $100 \%$ of patients with RAC present (35/35) were found to be $H$. pylori-negative. A further study by the same group recruited 500 patients to assess the benefit of using a "site-specific biopsy" of abnormal mucosa rather than random biopsy for the diagnosis of $H$. pylori. Increases in sensitivity and specificity to $95.4 \%$ and $97.3 \%$ were noted (from $93.0 \%$ and $88.6 \%$ respectively) [21].
The first prospective study for real-time use of both WLE and NBI was performed in 2014 and 2015 by Pimental-Nunes et al. This was a multicenter study involving sites in Portugal, Italy, Romania, the United States, and the UK [22]. The study primarily investigated diagnosis of premalignant gastric lesions including metaplasia and dysplasia, and introduced an endoscopic classification system for these lesions, which included H. pylori gastritis (characterized as variable vascular density, with a normal corpus mucosa). A total of 238 patients were examined, first with WLE and then NBI. For diagnosis of $H$. pylori infection, the accuracy of WLE and NBI was similar (73\% and $74 \%$ respectively). NBI showed slightly higher sensitivity and slightly reduced specificity, but this was not statistically significant. Although not the primary outcome of the study, this is the only study to have prospectively assessed diagnostic accuracy of $\mathrm{NBI}$ for $\mathrm{H}$. pylori in real time.

The role of $\mathrm{NBI}$ in assessment of $\mathrm{H}$. pylori infection continues to develop. The earliest study under clinical conditions has not shown accuracy enough to confidently diagnose $H$. pylori without biopsy or alternative diagnostic method, [22] but it may be that the benefits of NBI come from the more accurate identification of abnormal mucosa, allowing targeted biopsies to be obtained, and increasing their diagnostic yield.

\section{i-scan digital chromoendoscopy}

To date, only one study has been published investigating diagnostic accuracy of non-magnified i-scan, a digital image enhancement technique incorporated into endoscopes from Pentax Medical (Tokyo, Japan). This was a prospective pilot study in 2017 which recruited 146 patients with symptoms of dyspepsia. A greater proportion of patients were identified as showing endoscopic features of $\mathrm{H}$. pylori under i-scan examination, (79/ 146 , compared to 45/146 under WLE) and the overall diagnostic accuracy of i-scan was reported as $97 \%$, compared with $78 \%$ for WLE. The diagnostic features used are not further elaborated. [23]

Comparable to NBI, i-scan offers the potential to gain more information from visual examination of the gastric mucosa, versus WLE, and is likely to develop a similar role. Newer endoscopic platforms from Pentax will integrate the second-generation "i-scan Optical Enhancement" (OE) which incorporates an optical filter and promises improved visual contrast.

\section{Blue laser imaging and linked-color imaging}

A recent innovation in endoscopic imaging is the LASEREO endoscopic platform, produced since 2013 by Fujifilm (Tokyo, Japan). This creates illumination by excitation of a phosphor at the endoscope tip, and can apply light from a second laser to create an altered color BLI mode [24]. In addition, the system incorporates $\mathrm{LCl}$ which further adjusts the colors and increases visual contrast.

The earliest study of $\mathrm{LCl}$ in $\mathrm{H}$. pylori infection was performed by Dohi et al. in 2016. This was a retrospective review of endoscopic images using LCl, from 60 patients: $30 \mathrm{H}$. pylori-positive, and 30 negative after eradication [25]. The diagnostic criterion applied was a diffuse redness of the fundus, which the investigators anticipated would be accentuated by LCI. The overall di- 
agnostic accuracy of $\mathrm{LCl}$ for $\mathrm{H}$. pylori was found to be $85.8 \%$, and there was moderate-good agreement between expert and nonexpert endoscopists.

Nishikawa et al. explored the diagnostic potential of BLI in 2017 by analysis of images obtained from 441 patients diagnosed with atrophic gastritis [26]. The mucosal patterns were classified as "spotty," "cracked" or "mottled" on retrospective review of the images by expert endoscopists. The spotty pattern was found to correlate with active $H$. pylori infection (77/ 89 patients) and the authors also suggest that the cracked pattern may represent post-inflammatory change after $H$. pylori eradication, and the mottled pattern may represent intestinal metaplasia resulting from $\mathrm{H}$. pylori-related gastritis.

The first real-time diagnostic study of $\mathrm{LCl}$ was performed in 2018 by Chen et al. and recruited 122 patients for examination by $\mathrm{LCl}$, with WLE and magnified endoscopy as comparators [27]. Patients underwent WLE, followed by LCI, and then magnified WLE. The diagnostic criterion applied was absence of the RAC. Diagnostic accuracy of $\mathrm{LCl}$ was reported as $78.4 \%$, with sensitivity and specificity of $70.8 \%$ and $81.3 \%$ respectively. This was not statistically different from examination under magnification, or if $\mathrm{LCl}$ and magnification were combined. Diagnostic accuracy of WLE alone was not reported in this study; it is unclear then if $\mathrm{LCl}$ provides an increase to diagnostic accuracy over standard endoscopy.

\section{Computer-aided diagnosis and artificial intelligence}

CAD is a rapidly progressing area within all endoscopic disciplines. Recent advances in processing power have permitted development of "deep learning" algorithms and convolutional neural networks (CNN), capable of analyzing an image for features including shapes, colors and textures. Developments in colonoscopy have shown the potential for lesion detection to be integrated into the endoscopic image seen by the operator [28], and there have been several studies investigating automated diagnosis of $H$. pylori infection by deep learning algorithms.

Early applications of these techniques were developed by Itoh et al. in 2017, who produced a deep learning algorithm based on the GoogLeNet CNN. This was trained using 149 endoscopic images under WLE from patients with known $H$. pylori status. When applied to a test series of 30 new endoscopic images, the CNN achieved a diagnostic sensitivity and specificity of $86.7 \%$ and $86.7 \%$ [29].

Shichijo et al. developed further CNNs capable of diagnosing $H$. pylori based on endoscopic images, in 2017 [30]. Two neural networks were trained, one on a database of 32,208 WLE images obtained from patients with known $\mathrm{H}$. pylori status, and the second on images classified by anatomical location in the upper gastrointestinal tract. Diagnostic performance of the combined CNN was compared with 23 endoscopists for analyzing a third set of 11,481 test images. An accuracy of $87.7 \%$ was achieved by the CNN, compared with $82.4 \%$ for the endoscopists. It was also notable that the time taken to produce the diagnoses was dramatically different, at 194 seconds for the CNN, compared with 230 minutes for the human endoscopists, demonstrating the potential for rapid CAD as an adjunctive tool during endoscopy.
CAD has also been studied for the newer endoscopic platforms; Nakashima et al. produced a CADalgorithm trained on images obtained using BLI-bright mode and $\mathrm{LCl}$ in addition to WLE [31.] This was a "transfer learning" model rather than a fully developed CNN, and was trained on a series of 162 images for each modality, then tested on a further 60 images for each. Sensitivity and specificity for WLE under CADanalysis were $66.7 \%$ and $60.0 \%$, respectively, but as anticipated by the authors, there was a dramatic increase when the BLI-bright and $\mathrm{LCl}$ images were analyzed, with sensitivity $96.7 \%$ for each modality, and specificity of $86.7 \%$ for BLI-bright, and $83.3 \%$ for $\mathrm{LCl}$. Furthermore, the algorithm produced "heat maps" demonstrating the region of interest to the artificial intelligence. This technique could be readily adapted to facilitate a strategy of targeted biopsy.

\section{Discussion}

Developments in quality of endoscopic imaging have presented the opportunity to advance frontiers of endoscopic diagnosis, and it has been well demonstrated that meticulous examination of the gastric mucosa can yield information regarding the $H$. pylori status of a patient. The current dilemma therefore concerns the appropriate way to apply this knowledge. It would be desirable to produce an accurate real-time diagnosis of $\mathrm{H}$. pylori status, which might prompt further testing or even negate the requirement for biopsy (for urease testing, histological examination or tissue culture) if an appropriate level of diagnostic accuracy is achieved. This degree of accuracy may be difficult to demonstrate in clinical practice, however, due to factors such as the heterogeneity of patient groups, concomitant medications, previous $H$. pylori infection, and variable distribution of infection. In addition, these tests are readily available in clinical use, and are relatively inexpensive. The acceptability of providing an "optical biopsy" diagnosis is unproven, for patients and clinicians

The studies included in this review use various methods as their "reference standard" for presence or absence of $H$. pylori infection. Serology, urea breath test, and fecal antigen testing were preferred as the confirmatory test, as there is potential for diagnostic inaccuracy from tests requiring biopsy (rapid urease test, tissue microscopy or culture). These may introduce sampling error, due to the nature of $H$. pylori infection, which may be patchy and can be missed by random biopsy sampling. Some of the studies included in this review use these methods, although the biopsy sampling protocol is not always fully elaborated. - Table 1 lists the reference standards applied in each study.

A potential benefit from understanding mucosal patterns associated with different $H$. pylori states could be in identifying areas of mucosa that are the most likely to harbor $H$. pylori, and thereby increase diagnostic yield of biopsy sampling by taking targeted, rather than random biopsies. Furthermore, an understanding of the different mucosal appearances will allow patients to be categorized as H. pylori-naïve, infected, or eradicated, and future studies on diagnostic accuracy should include these categories. 
Several different image enhancement modalities were investigated for their ability to better define mucosal features. Six of these studies investigated NBI (Olympus), three studies investigated BLI and LCl imaging modes (Fuji) and one study investigated i-scan (Pentax). Each of these technologies aims to enhance the contrast of mucosal surface features, and the resultant altered color images are similar, but not entirely the same. There is little information about the preferred imaging modality and practice of endoscopists, but if a unified approach to assessment of $H$. pylori is to be developed, then it will be important to understand similarities and differences between the images from the different technologies. This could be achieved by studies with multiple patient groups, allocated to different equipment, or could perhaps be assessed by review of images taken at endoscopy, to assess the intra- and inter-operator agreement for different technologies.

In common with other areas of endoscopic practice, CAD of $H$. pylori is a rapidly developing field, with great potential to aid clinicians. Early studies demonstrate very high diagnostic accuracy, although it must be remembered that these are under optimized conditions, and tested on static images rather than real-time, in vivo. The "deep learning" of convolutional neural networks is commonly described as a "black box" system - the input (image) and the output (diagnosis) are known, but the processes by which the diagnosis is achieved are not. Understanding which characteristics are identified by the CNN can allow a new appreciation of the changes associated with disease. There are different methods used to understand the logic processes of a CNN, for example, the imaging "heat maps" illustrate what parts of an image the CNN has used for discrimination of $H$. pylori status. Other methods include altering the inputs given to the algorithm and studying changes to the outputs. As deep learning algorithms come to play an increasing role in diagnosis, it will become increasingly important to "open the black box" to understand the functioning within, for academic, legal and ethical purposes. [32]

\section{Conclusions}

Several features of the stomach mucosa can be identified without specialist endoscopy as predictors of $H$. pylori status. Importantly, presence of RAC may rule out current or previous $H$. pylori infection with sensitivity of $>90 \%$. This has been supported by multiple image analyses, although has not yet been validated prospectively. Studies of automated image analysis have demonstrated the ability to distinguish between different $H$. pylori status, although this research is currently at the stage of retrospective analysis only.

The aim of future research should now be to validate diagnostic accuracy of the discovered features and the CAD approaches, with the aim of proposing a simple classification system for endoscopic prediction of $H$. pylori status. This should attempt to stratify endoscopic appearances of an area of mucosa into "low probability" or "high probability" of harboring H. pylori infection. Future research should include robust prospective clinical trials in which the diagnosis is made during the endoscopic procedure, whether made by a clinician or by a
CAD technique. Ideally, patients would be categorized as $\mathrm{H}$. pylori-naïve, infected or eradicated using reliable methods such as serology and urea breath testing. External validity of a proposed classification would be maximized by studying a heterogeneous group of patients, as many of the studies currently available exclude patients with previous $H$. pylori, or patients taking proton pump inhibitors. A classification system would also be most useful if it could be applied with confidence when using all forms of image enhancement, as well as WLE. Adoption of such a classification system could improve endoscopists' confidence in their diagnoses and improve diagnostic yield of biopsy samples. The role of CAD may be as an adjunct to clinical judgement, and to improve the confidence of clinical decisions.

\section{Competing interests}

None

\section{References}

[1] Venerito M, Vasapolli R, Rokkas T et al. Gastric cancer: epidemiology, prevention, and therapy. Helicobacter 2018; 23 : (Suppl. 01): e12518

[2] Wong BC, Lam SK, Wong WM et al. Helicobacter pylori eradication to prevent gastric cancer in a high-risk region of China: a randomized controlled trial. JAMA 2004; 291: 187-194

[3] Cho JH, Jeon SR, Kim HG et al. Factors for improving the diagnostic efficiency of the rapid urease test from the gastric corpus. Scand J Gastroenterol 2017; 52: 1320-1325

[4] Skrebinska S, Megraud F, Bessede E. Diagnosis of Helicobacter pylori infection. Helicobacter 2018; 23 : (Suppl. 01): e12515

[5] Qi Q, Guo C, Ji R et al. Diagnostic performance of magnifying endoscopy for Helicobacter pylori Infection: A meta-analysis. PLoS ONE 2016; 11: e0168201

[6] Bah A, Saraga E, Armstrong D et al. Endoscopic features of Helicobacter pylori-related gastritis. Endoscopy 1995; 27: 593 - 596

[7] Laine L, Cohen H, Sloane R et al. Interobserver agreement and predictive value of endoscopic findings for $\mathrm{H}$. pylori and gastritis in normal volunteers. Gastrointest Endosc 1995; 42: 420 - 423

[8] Redéen S, Petersson F, Jönsson K-Å et al. Relationship of gastroscopic features to histological findings in gastritis and Helicobacter pylori infection in a general population sample. Endoscopy 2003; 35: 946 950

[9] Yagi K, Nakamura A, Sekine A. Characteristic endoscopic and magnified endoscopic findings in the normal stomach without Helicobacter pylori infection. J Gastroenterol Hepatol 2002; 17: 39-45

[10] Machado RS, Viriato A, Kawakami E et al. The regular arrangement of collecting venules pattern evaluated by standard endoscope and the absence of antrum nodularity are highly indicative of Helicobacter pylori uninfected gastric mucosa. Dig Liver Dis 2008; 40: 68-72

[11] Alaboudy A, Elbahrawy A, Matsumoto $S$ et al. Regular arrangement of collecting venules: Does patient age affect its accuracy? World J Gastrointest Endosc 2011; 3: 118-123

[12] Yan SL, Wu ST, Chen CH et al. Mucosal patterns of Helicobacter pylorirelated gastritis without atrophy in the gastric corpus using standard endoscopy. World J Gastroenterol 2010; 16: 496-500

[13] Matrakool L, Tongtawee T, Bartpho T et al. Improved detection of Helicobacter pylori infection and premalignant gastric mucosa using conventional white light source gastroscopy. APJCP 2016; 17: 2099 2103 
[14] Cho JH, Chang YW, Jang JY et al. Close observation of gastric mucosal pattern by standard endoscopy can predict Helicobacter pylori infection status. J Gastroenterol Hepatol 2013; 28: 279-284

[15] Gomes A, Skare TL, Prestes MA et al. Conventional videoendoscopy can identify Helicobacter pylori gastritis? Arq Bras Cir Dig 2016; 29: $73-76$

[16] Watanabe K, Nagata N, Shimbo T et al. Accuracy of endoscopic diagnosis of Helicobacter pylori infection according to level of endoscopic experience and the effect of training. BMC Gastroenterol 2013; 13 : $128-135$

[17] Alaboudy AA, Elbahrawy A, Matsumoto $S$ et al. Conventional narrowband imaging has good correlation with histopathological severity of Helicobacter pylori gastritis. Dig Dis Sci 2011; 56: 1127-1130

[18] Hayashi S, Imamura J, Kimura K et al. Endoscopic features of lymphoid follicles in Helicobacter pylori-associated chronic gastritis. Dig Endosc 2015; $27: 53-60$

[19] Ozgur T, Ozkan TB, Erdemir G et al. The diagnostic value of endoscopic narrow band imaging in helicobacter pylori gastritis in children. Turk J Gastroenterol 2015; 26: 112-116

[20] Tongtawee T, Kaewpitoon S, Kaewpitoon N et al. Correlation between gastric mucosal morphologic patterns and histopathological severity of Helicobacter pylori associated gastritis using conventional narrow band imaging gastroscopy. BioMed Res Int 2015; 2015: 808505

[21] Tongtawee T, Dechsukhum C, Leeanansaksiri W et al. Improved detection of Helicobacter pylori infection and premalignant gastric mucosa using "site specific biopsy": a randomized control clinical trial. APJCP 2015; 16: $8487-8490$

[22] Pimentel-Nunes P, Libanio D, Lage J et al. A multicenter prospective study of the real-time use of narrow-band imaging in the diagnosis of premalignant gastric conditions and lesions. Endoscopy 2016; 48: $723-730$
[23] Sharma VSaini S, Saini S et al. High efficacy of i-scan endoscopy in the diagnosis of Helicobacter pylori infection. Clin Gastroenterol Hepatol 2017; 15: 154

[24] Morimoto Y, Kubo M, Kuramoto M et al. Development of a new generation endoscope system with lasers "LASEREO". Fujifilm Research And Development 2013; 58: 1-6

[25] Dohi O, Yagi N, Onozawa Y et al. Linked color imaging improves endoscopic diagnosis of active Helicobacter pylori infection. Endosc Int Open 2016: 04

[26] Nishikawa Y. Classification of atrophic mucosal patterns on Blue LASER Imaging for endoscopic diagnosis of Helicobacter pylori-related gastritis: A retrospective, observational study. PLoS On 2018; 13: e0193197

[27] Chen TH, Hsu CM, Cheng HT et al. Linked color imaging can help gastric Helicobacter pylori infection diagnosis during endoscopy. JCMA 2018; 81: 1033-1037

[28] Urban G, Tripathi P, Alkayali T et al. Deep learning localizes and identifies polyps in real time with $96 \%$ accuracy in screening colonoscopy. Gastroenterology 2018; 155: 1069-1078.e1068

[29] Itoh T, Kawahira H, Nakashima $\mathrm{H}$ et al. Deep learning analyzes Helicobacter pylori infection by upper gastrointestinal endoscopy images. Endosc Int Open 2018; 6: E139-144

[30] Shichijo S, Nomura S, Aoyama K etal. Application of convolutional neural networks in the diagnosis of Helicobacterpylori infection based on endoscopic images. EBioMedicine 2017; 25: $106-111$

[31] Nakashima $\mathrm{H}$, Kawahira $\mathrm{H}$, Kawachi $\mathrm{H}$ et al. Artificial intelligence diagnosis of Helicobacter pylori infection using blue laser imaging-bright and linked color imaging: a single-center prospective study. Ann Gastroenterol 2018; 31: 462-468

[32] Holm EA. In defense of the black box. Science 2019; 364: 26 - 27 